\title{
Eduard Ahrensin kielioppi ja suomalaiset
}

\author{
HANNU REMES
}

Tiivistelmä. Turun Akatemian professori H. G. Porthan edisti Suomessa 1800-luvun taitteessa monipuolisesti tutkimusta ja oli kiinnostunut sekä suomen kielestä että sukukielistämme. Hänen mukaansa kielten tuntemuksen kannalta olivat tärkeitä kieliopit, ja hän kaipasi virosta kielioppia, joka vastaisi paremmin kielen rakennetta kuin siihen mennessä julkaistut, latinan kieliopin mallia noudattaneet teokset. Vihdoin 1843 ilmestyi Kuusalun pastorin Eduard Ahrensin laatima saksankielinen viron kielioppi, jonka esikuvana oli käytetty kieltä tyydyttävämmin kuvaavaa suomen kielioppia. Luonteeltaan teos oli kontrastiivinen. Ahrens ajoi voimakkaasti viron oikeinkirjoituksen uudistamista suomen mukaiseksi.

Elias Lönnrot teki 1844 puolivuotiseksi venyneen tutkimusmatkan Viroon. Hän tutustui Ahrensiin ja keskusteli tämän kanssa kieliopin ja ortografian kysymyksistä. Lönnrot pyrki Tartossa oleskellessaan vaikuttamaan osaltaan Viron Oppineiden Seuran jäseniin oikeinkirjoituksen uudistamista puoltaen. Hänen tarkoituksenaan oli myöhemmin hyödyntää Ahrensin kielioppia ja Virossa omaksumaansa hyvää kielitaitoa vertailevan suomen, viron, saamen ja vepsän kieliopin laatimisessa. Hän lähetti Suomeen matkakirjeissään runsaasti havaintoja suomen ja viron suhteista.

Syksyllä 1854 Virossa vieraili muutaman kuukauden ajan August Ahlqvist, joka oli toistuvasti korostanut kieliopin merkitystä. Hän suhtautui kuitenkin Ahrensin kielioppiin varsin kielteisesti ja piti sitä sekavana sekä huonosti oppikirjaksi sopivana. Myönteistä oli vain Ahrensin pyrkimys ortografian uudistamiseen. Ahlqvist teki kuitenkin Suomessa merkittävän työn viron 
kielen opetuksen ja tutkimuksen edistämiseksi, ja hänen ansiostaan koheni alan oppikirjatilanne huomattavasti.

Vuonna 1872 ilmestyi Julius Krohnin laatima Wiron Kielioppi Suomalaisille, ensimmäinen laatuaan. Krohn käytti sitä kirjoittaessaan tärkeimpinä lähteinään Ahrensin kielioppia, mistä sai Ahlqvistin tekemässä arvostelussa moitteita, ja Wiedemannin virolais-saksalaista sanakirjaa. - Voidaan sanoa, että Ahrensin kielioppi vaikutti Suomessa epäsuorasti, Krohnin teoksen välityksellä, vielä vuosikymmeniä ilmestymisensä jälkeen kuvaan viron kielen luonteesta ja rakenteesta. ${ }^{1}$

Avainsanat: viron kielioppi; viron opetus; Eduard Ahrens; Elias Lönnrot; August Ahlqvist; Julius Krohn

\section{Johdanto}

Turun Akatemian professori Henrik Gabriel Porthan (1739-1804), jota on kutsuttu Suomen historian isäksi, edisti aikanaan monipuolisesti kansallisten tieteiden tutkimusta ja oli kiinnostunut muun muassa suomesta ja sen sukukielistä. Hänen julkaisuihinsa kuului kielitieteellisiä tutkimuksia, joista merkittävin oli De praecipuis dialectis linguae Fennicae (Suomen kielen päämurteista, 1801). Porthanin (1982: 161) mukaan Suomen ja Viron kansojen läheistä sukulaisuutta osoitti se, että ne puhuivat saman kielen eri murteita.

Porthan esitti murretutkimuksessaan, että kielten tuntemuksen kannalta ovat tärkeitä niistä laaditut kunnolliset kieliopit. Suomen osalta hän kiitteli Bartholdus Vhaelia, jonka teos Grammatica Fennica oli ilmestynyt postuumisti 1733 ja jossa oli irtauduttu aikaisempia kielioppeja kahlinneesta latinan kieliopin mallista. Esimerkiksi sijamuotojen määrä oli 14, ja niiden kuvaus on miltei nykyisellä kannalla (Häkkinen 1994: 106). Vhaelin kieliopissa oli kiinnitetty myös huomiota suomen murteisiin, joiden yhdistäjänä oli kirjakieli. Porthan piti valitettavana,

$1 \quad$ Artikkeli perustuu Kuusalussa 10.8.2019 Laurentiuksen päivän virolais-suomalaisessa konferenssissa pidettyyn esitelmään Eduard Ahrensi grammatika ja soomlased. 
etteivät viron tutkijat olleet ymmärtäneet hyödyntää Vhaelin kielioppia, vaan he edelleen esittivät nomineilla olevan kuusi sijaa. Hän viittasi A. W. Hupelin 1780 ilmestyneeseen teokseen Ehstnische Sprachlehre, jonka tekijäkin totesi, että sijanmuodostuksessa vallitsi suuri säännöttömyys ja epävakaisuus. Puutteellisuuksia oli myös verbien taivutuksen kuvauksessa. Sukukieltemme oikean luonteen ymmärtämiseksi pitäisi hylätä latinan kieliopin malli, kuten Vhael oli tarkkanäköisesti tehnyt. (Porthan 1982 [1801]: 322.) Virossa tämä ongelma väistyi vasta vuonna 1843, kun ilmestyi Kuusalun pastorin Eduard Ahrensin kielioppi Grammatik der Ehstnischen Sprache Revalschen Dialektes, joskin siellä oli jo aiemmin kiinnitetty asiaan huomiota (mm. Knüpffer 1817 ja 1821, Heller 1822 ja Faehlmann 1842, ks. Viht \& Habicht 2020: 210-211).

\section{Elias Lönnrot Virossa}

Kalevalan kokoaja Elias Lönnrot (1802-1884) oli todennäköisesti ensimmäinen suomalainen tutkija, joka tutustui Eduard Ahrensin viron kielioppiin. Kesäkuussa 1844 hän matkusti laivalla Viroon ja pian Tallinnaan saavuttuaan jatkoi matkaa Kuusaluun kieliopin tekijän luo. Suomalaisella oli mukanaan Ahrensin hämmästykseksi tuore kielioppi, jonka tämä oli ehtinyt lahjoittaa Suomalaisen Kirjallisuuden Seuralle (kirje Rabbelle 21.7./2.8.1844, Lönnrot 1902: 241-242). Lönnrot oli halunnut valmistautua hyvin Viron-matkaansa ja oli lainannut kieliopin seuran kirjastosta.

Elias Lönnrot teki kaikkiaan yksitoista keruu- ja tutkimusmatkaa, joista Viroon suuntautunut jäi hänen viimeisekseen. Matkan tarkoituksena oli paitsi kielen opiskelu myös aineiston kerääminen suurta suomalais-ruotsalaista sanakirjaa varten, jonka Suomalaisen Kirjallisuuden Seura oli vuonna 1840 antanut hänen tehtäväkseen. Tuohon aikaan ajateltiin yleisesti, että itämerensuomalaiset kielimuodot olivat pikemminkin murteenomaisessa suhteessa toisiinsa kuin eri kieliä, ja Lönnrot toivoi saavansa niistä aineksia suomen sanaston kehittämiseen. Hän suunnitteli (kirjeet Snellmanille 13.8.1844 ja Ståhlbergille 24.8.1844, 
Lönnrot 1990: 223, 225) myös vertailevan suomen, viron, saamen ja tšuudin (vepsän) kieliopin laatimista, mutta valitettavasti tämä hanke ei koskaan toteutunut.

Elias Lönnrot oli perehtynyt jossain määrin viron kieleen jo ennen matkaansa. Hän tunsi J. H. Rosenplänterin Beiträge-aikakausjulkaisut ja esimerkiksi A. W. Hupelin kieliopin, jonka toinen painos (1818) kuului hänen käsikirjastoonsa Itä-Karjalaan ja Äänisjärven takaiselle itävepsäläisten alueelle suuntautuneella tutkimusmatkalla 1841 (Majamaa 1990: 518). Vuoden 1843 lopulla Lönnrot oli saanut valmiiksi laajan kokoelman Suomen Kansan Arwoituksia. Hän oli liittänyt siihen 135 virolaista arvoitusta vertailuaineistoksi ja samalla kielennäytteiksi lukijalle, "jolla ei ole tilaisuutta Viron kieltä muissa kirjoissa nähdä” (Lönnrot 1991 [1844]: 393). Arvoitukset oli myös varustettu suomennoksin.

Suomalaisen Kirjallisuuden Seura oli jo vuonna 1841 ilmoittanut Viron Oppineiden Seuralle (ÕES), että Elias Lönnrot matkustaisi piakkoin Viroon solmimaan suhteita sekä tutkimaan kansanrunoutta ja kieltä. Itä-Karjalan-matkan ja muiden töiden vuoksi suunnitelma toteutui kuitenkin vasta 1844 , mitä voi pitää sikäli onnekkaana sattumana, että Ahrensin uudentyyppinen kielioppi oli ehtinyt ilmestyä sopivasti edellisenä vuonna (Lönnrotin matkasta ks. mm. Anttila 1985: 302-305; Niit 1986; Remes 2003: 185-188).

Lönnrotin vierailu Ahrensin luona merkitsi ensimmäistä Suomen ja Viron kielentutkijoiden tapaamista. Miehet olivat miltei samanikäisiä: Lönnrot oli syntynyt 9. huhtikuuta 1802, Ahrens puolestaan uuden kalenterin mukaan 3. huhtikuuta vuotta myöhemmin. Heidän keskusteluissaan kosketeltiin epäilemättä kielioppiasioita ja erityisesti viron ortografian uudistamista suomen mallin mukaan. Nämä ajankohtaiset aiheet kiinnostivat viroon perehtyvää Lönnrotia; tuskin hän muuten olisi poikennut Kuusaluun tapaamaan tuoreen kieliopin tekijää (Kask 1958: 56-57; Anttila 1985: 303). Ahrens puolsi oikeinkirjoitusreformia, vaikka käyttikin kieliopissaan vielä vanhaa ortografiaa lukuun ottamatta loppuun sijoitettua parikymmensivuista etymologista sanaluetteloa, jonka kirjoitusasu oli uudentyyppinen (Ahrens 1843; Kask 1970: 169; Kasik 
1999: 48). Jo Ahrensin kanssa käydyt keskustelut ja tämän kielioppi saivat Lönnrotin havaitsemaan, miten keskeisessä asemassa oli tuolloin Virossa ortografiaa koskeva mielipiteenvaihto. Tilannetta oli omiaan hämmentämään myös kahden kirjakielen käyttö. (Ks. esim. kirje Rabbelle 21.7./2.8.1844, Lönnrot 1902: 241-244.)

Elias Lönnrotin ja Eduard Ahrensin tapaaminen Kuusalussa jäi valitettavasti melko lyhyeksi, sillä pastorin oli kiirehdittävä muutaman päivän kuluttua Tallinnaan pappeinkokoukseen. Lönnrotin matka jatkui Koerun kautta Tarttoon. Siellä hän tutustui pian Friedrich Robert Faehlmanniin, jonka kielioppia käsitelleet artikkelit olivat Ahrensin teoksen ohella jo herättäneet hänen huomiotaan (Lönnrot 1990 [1844]: 221). Faehlmannista tuli Lönnrotin paras virolainen ystävä, joka suuresta työkuormastaan huolimatta ehti antaa hänelle viron kielen tunteja. Eri mieltä he olivat kuitenkin ortografian uudistamisesta.

Lönnrot moitiskeli jo ensimmäisissä matkakirjeissään, kuinka viron oikeinkirjoitus oli hyvin puutteellista (ks. esim. Lönnrot 1902 [1844]: 243). Syksyllä Tartosta Jacob Zittingille lähettämässään kirjeessä hän valitteli. "Oppinut seuran esimiehen Tohtori Faehlmannin ja muiden kanssa on minulla aina ollut tyhjää tekemistä ja vastaamista Suomen kielen kirjoituslaadun (Orthografian) puolesta. (He) päättivät sen aivan kelpaamattomaksi ja luulevat Wiron kirjoituslaadun paljo paremmaksi Suomellenkin sopivammaksi. - - Miksi siansaksaksi suomi sillä tavalla kirjoitettuna muuttuisi, kyllä helposti on nähtävä, ja samanlaiseksi on se jo muuttanut Wiron kielen." Suomenkielisenä esimerkkinä on viron vanhan ortografian mukaisesti kirjoitettu Kanteletteren runo, ja sitä suomalaisen on todella vaikea lukea. Lönnrot oli kuitenkin rauhaa rakastava mies ja selitti, että hän oli riitelemisen sijaan käskenyt seuran miehiä matkustamaan Suomeen, opiskelemaan kieltämme ja vasta sitten puhumaan oikeinkirjoituksesta. (Lönnrot 1990 [1844]: 232-233) Lönnrot toivoi voivansa käsitellä Viron Oppineiden Seuran kokouksessa oikeinkirjoituskysymystä, mikä näyttää onnistuneenkin, sillä seuran arkistosta löytyy nelisivuinen käsikirjoitus Etwas über die Finnische Orthographie (Lönnrot 1990 [1844]: 233; Majamaa 1990: 527). 
Ahrensin kieliopin, Faehlmannin opetuksen ja oman ahkeruutensa ansiosta Lönnrot saattoi kirjoittaa elokuussa C. H. Ståhlbergille (Lönnrot 1902 [1844]: 251): “Täällä Tartossa olen jo puolentoista kuukautta tutkinut viroa ja etenkin viron kielioppia, joka nyt vihdoinkin on alkanut selvitä minulle." Hän katsoi tästä olevan hyötyä myös tulevaisuudensuunnitelmissa väikkyneen suomen, viron, vepsän ja saamen vertailevan kieliopin kirjoittamiseen. Lönnrotin kielitaidosta löytyy myös aikalaistodistus: Rõugen pastori Carl Reinthal, jonka luona Lönnrot oleskeli kymmenisen päivää Tartosta eteläisimpään Viroon tekemällään matkalla, merkitsi kirkonkirjaan, että suomalaisvieras oli kielellisesti huomattavan lahjakas ja osasi viroa niin hyvin, että tunsi sen hienoimmatkin vivahteet (Kuningas 1977: 239-240). Reinthal kuului niihin, jotka suhtautuivat viron ortografian uudistamispyrkimyksiin myönteisesti, ja tiedetään hänen saaneen vahvistusta ajatuksilleen ja toiminnalleen Lönnrotin kanssa käymistään keskusteluista (Kask 1958: 60, 113).

Eduard Ahrens (1843: 5) esitti kielioppinsa johdannon ensimmäisessä lauseessa juhlallisesti, että viro on suomen kielen tytär, eikä hän ollut Virossa ainoa tämän kannan edustaja. Lönnrotin mielestä oli kuitenkin kyse pikemminkin sisarkielistä. Hän halusi valita, kuten hän elokuussa kirjoitti C. H. Ståhlbergille (Lönnrot 1990 [1844]: 225), kahdesta pahasta pienemmän, mieluummin "pilatun sisaren kuin pilatun lapsen". Faehlmannkaan ei ollut Ahrensin kannalla, mutta hänen mukaansa virolaiset ja suomalaiset puhuivat saman kielen eri murteita. Suomen kielen tai murteen ja Tallinnan viron ero oli suunnilleen yhtä suuri kuin Tallinnan ja Tarton murteiden ero. (Kask 1970: 160-161.)

Matkakirjeissään (mm. C. H. Ståhlbergille 24.8.1844 ja F. J. Rabbelle 27.8.1844, Lönnrot 1990: 225-228) Lönnrot esitti kiinnostavia havaintoja viron kielen tärkeimmistä ominaispiirteistä, jotka erottivat sitä suomesta. Hän mainitsi esimerkiksi, että viron sanat ovat usein suomen sanoja lyhyempiä. Yhtenä syynä on sisäheitto: nuhtlen - nuhtelen, viimne - viimeinen, tütred - tyttäret. Tämä piirre näytti vielä tukevan Ahrensin käsitystä, että viron kielen sananmuodot ovat usein kehittyneet lyhenemällä vastaavista suomen muodoista. Mutta kun Lönnrot 
toi lyhemmyydestä esimerkkeinä konsonanttiin päättyvät nominatiivit, joiden suomalaisissa vastineissa on lopussa vokaali, kuten saun - sauna, madal - matala, hän ei puhunutkaan Ahrensin tavoin lyhenemisestä, loppuheitosta, vaan piti viron muotoja alkuperäisempinä ja arveli suomalaisten lisänneen sanan loppuun vokaalin. Samantyyppinen käsitys hänellä oli suomessa vokaaliin mutta virossa lyhyempien, konsonanttiin päättyvien sijamuotojen suhteista, esimerkiksi sauna/st - sauna/sta, isa/ks - isä/ksi. (Ks. myös Lönnrot 1991 [1854]: 81.)

Lönnrot totesi kirjeissään niin ikään, että viron sijamuodoista puuttuivat komitatiivi, instruktiivi, essiivi ja prolatiivi, mutta kiinnitti huomiota $g a$-loppuiseen muotoon, jonka käyttö vastasi monessa suhteessa suomen komitatiivia: käega, Jumalaga. Samoin hän huomautti, että virossa on ni-päätteinen terminatiivi rinnani, pólveni, jollainen suomesta puuttuu. Lönnrot ei ymmärtänyt, miksi terminatiivi oli Ahrensin kieliopissa jätetty ottamatta sijamuotoihin, mutta tämähän ei pitänyt komitatiivia eikä terminatiivia sijoina, koska niiltä puuttuivat suomesta muotovastineet. Ahrens (1843: 93) mainitsi kyllä suffiksit ga ja ni, mutta prepositioita koskevassa luvussa nähtävästi siksi, että niiden käyttö vastasi saksan prepositioilmauksia; merkityksenselityksinä ovatkin 'mit' ja 'bis'. Hänen mukaansa ni-suffiksin alkuperä oli tuntematon, mutta kielioppinsa toiseen painokseen hän (1853:118) lisäsi selityksen - kylläkin virheellisen -, että se olisi kehittynyt suomen illatiivin päätteestä ja antoi esimerkkinä rinnastuksen suomen puoli-yöhön = viron poole ööni.

Lönnrotin esittämä käsitys essiivin puuttumisesta viron sijavalikoimasta perustui ilmeisesti hänen matkallaan tekemiinsä havaintoihin. Ahrens oli kieliopissaan (1843: 51) kylläkin ottanut essiivin sijojen joukkoon, mutta samalla todennut, että vaikka muoto oli kirjakielessä täysin tuntematon, se ansaitsisi kuulua sijamuotosarjaan. Kuusalun pastori tunsi essiivin kansankielestä; Koillis-Viron rantamurteen alue oli ainoa, jossa se esiintyi produktiivisena sijana (Rätsep 1979: 63-64).

Elias Lönnrot ei tavannut Eduard Ahrensia toistamiseen, mikä olisi ollut mahdollista, jos hän olisi voinut Viron-matkaltaan palata Suomeen Tallinnan kautta (Niit 1986: 329). Töiden venyminen suunniteltua 
pitemmälle syksyyn merkitsi sitä, että Suomenlahden ylittäminen laivalla ei käynyt enää päinsä, vaan Lönnrotin oli tultava maitse Narvan ja Pietarin kautta Helsinkiin. Tiedetään hänen kuitenkin tarvinneen Ahrensin kielioppia myöhemminkin, kun hän suomen kielen professorina valmisteli sukukieliä käsitteleviä luentojaan (Wichmann 1928: 295; Anttila 1985: 393).

\section{August Ahlqvist - Ahrensin ankara kriitikko}

Kymmenen vuotta Lönnrotin käynnin jälkeen, syksyllä 1854, teki Viroon tutkimusmatkan kielitieteilijä August Ahlqvist (1826-1889). Hän suunnitteli vatjan kieliopin kirjoittamista, mutta huomasi, että "viron kielen tuntemus on välttämätön tarkasteltaessa lähemmin vatjalaisten murretta" (Ahlqvist 1982 [1854]: 44). Hän kirjoitti (1982 [1854]: 43) Virosta Lönnrotille pian maahan saavuttuaan: “Tämän kielen päätemput luulen parissa eli kolmessa kuukaudessa tulevani tuntemaan, ja sitten on Watjalaisten kielikin helpompi."

Ahlqvist oli jo vuonna 1848 käynyt Lönnrotin kanssa kirjeenvaihtoa viron ja suomen suhteista ja esittänyt selvästikin niiden puutteellista tietämystä osoittavan ajatuksen kirjakielten yhdistämisestä. Hänen mielestään (1982 [1848]: 26-27) saksalaiset olivat pilanneet viron ortografian, mutta tilanne korjaantuisi, jos Viroon lähetettäisiin Suomesta "kielen tuntija mies, joka kirjoittaisi Wirolaisille uuden kieliopin ja muuten pelmuutteleisi Saksalaisia". Ahlqvistille olikin kielten tuntemisen ja opiskelun kannalta keskeistä kielioppien merkitys. Lokakuussa 1854 hän osallistui Tartossa Viron Oppineiden Seuran kokoukseen ja luovutti seuralle Gustav Erik Eurénin pari vuotta aikaisemmin ilmestyneen teoksen Suomalainen Kielioppi Suomalaisille näytteenä suomen kielen tutkimuksesta (Haltsonen 1961: 224).

Eduard Ahrensin laatiman viron kieliopin toinen, täydennetty painos oli ilmestynyt Ahlqvistin matkaa edeltäneenä vuonna. Huomiota herättää, ettei Ahlqvist arvostanut teosta, vaikka sen esikuvana oli suomen kielioppi. Hän suhtautui siihen varsin nuivasti ja kirjoittikin (1982 
[1855]: 49) pian Tarton-vierailunsa jälkeen Emil Sachssendahlille: "Varsinkin viron kieliopille murretutkimukset olisivat erittäin tärkeitä, koska tutkija vain tällä tavoin saattaa ponnistella päämäärään, joka virolaisilta grammaatikoilta Fählmannia lukuun ottamatta tyyten puuttuu, nim. viron kielen tuntemiseen.” Myöhemmässä kirjeessään Sachssendahlille Ahlqvist (1982 [1855]: 67) totesi: "Mitä enemmän olen kuitenkin tutkinut kielitiedettä, sitä selvemmin olen havainnut, mitä sekasotkua A:n [Ahrensin] kansatieteellinen kielioppi on." Vielä pari vuosikymmentä myöhemmin hän moitti Ahrensin kielioppia arvostellessaan Kielettäressä teoksen käyttöä yhtenä Julius Krohnin Wiron Kieliopin (1872) lähteenä: Ahrensin kielioppi on tuntunut vastahakoiselta suomalaisista "lukijoista, jotka ovat tottuneet suomalaisen kieliopin selvyyteen ja säännöllisyyteen". (Ahlqvist 1874: 50-51.)

Ahrensin kielioppiin sisältyi liitteenä pieni etymologinen sanasto. Ahlqvist julkaisi marraskuussa 1854 tarttolaisessa viikkolehdessä Das Inland sen tulkintoja kritisoivan artikkelin Einige Missgriffe im etymologischen Wörterbüchlein des Herrn Pastor Ahrens. Ahrens loukkaantui siitä ja kirjoitti lehteen ironisen vastineen, jossa hän kiisti useimmat Ahlqvistin esittämät oikaisut. Hän oli asiasta pitkään kiukustunut, kuten osoittavat Ahlqvistin vielä seuraavana vuonna Virosta saamat viestit. (Põldmäe 1976: 490; Ahlqvist 1982 [1855]: 66.) - Samoihin aikoihin kuin Ahlqvist esitti Ahrensin kieliopista jyrkkiä mielipiteitään, julkaisi F. J. Wiedemann Pietarissa teoksesta perusteellisen arvostelun, jossa hän teki tekstiin joukon korjauksia ja parannusehdotuksia. Lisäksi hän moitti Ahrensia siitä, että tämä oli ollut liian riippuvainen suomen kieliopista, jota ei kuitenkaan tuntenut riittävän hyvin. Wiedemann tiesi Ahrensin loukkaantuvan herkästi ja kirjoitti arvostelunsa - toisin kuin Ahlqvist diplomaattisesti ja korosti myös Ahrensin merkittäviä ansioita. (Ariste 1973: 40, 42-43.)

August Ahlqvist oli ahkera kirjoittaja ja julkaisi nopeasti vatjalaisalueelle ja Viroon suuntautuneen matkansa tuloksia. Jo loppuvuodesta 1855 ilmestyi Suomi-sarjassa hänen teoksensa Wiron nykyisemmästä kirjallisuudesta. Se oli varhaisimpia suomenkielisiä tieteellisiä tutkimuksia 
ja ensimmäinen merkittävä suomenkielinen Viron sivistysoloista kertova teos. Ahlqvistin kirjallisuudenhistoria ulottui painetun virolaisen kirjallisuuden alkuvaiheista "nykyisen Wirolaisuuden pylvästen" Faehlmannin ja Kreutzwaldin toimintaan. Taaskin Ahrens sai moitteita. Viron kielen säännöt, joita hänellä oli vielä uudessakin kielioppinsa painoksessa, olivat paljon epäselvempiä ja mutkikkaampia kuin Faehlmannin kieliopillisissa artikkeleissaan esittämät. Vaikka Ahrensin kielioppi oli aineistonsa osalta vertaansa vailla, se "samalla myös sekavuutensa ja epätieteellisyytensä vuoksi on milt'ei aivan kelvotoin käyttää". Alaviitteessä kirjoittaja huomautti, että Ahrens "on ainoa kielentutkija Wirossa, joka vähän paremmin tuntee suomen kielen ja sen asiat, ehkä hänkin niissä useasti tekee sekä naurettavia että surettavia erhetyksiä'. (Ahlqvist 1856: 100-101.)

Huolimatta August Ahlqvistin kriittisestä ja osin ymmärtämättömän ankarasta suhtautumisesta Ahrensin kielioppiin ovat hänen ansionsa Suomessa viron kielen opetuksen ja tutkimuksen edistäjänä huomattavat. 1800-luvulla olivat Helsingin yliopistossa aikaisemmin käsitelleet viroa luennoillaan yliopiston ensimmäinen suomen kielen lehtori Carl Niklas Keckman sekä professori Elias Lönnrot, jotka olivat yleensä verranneet sitä eräiden muiden sukukielten ohella suomeen (Pääkkönen: 1994: 98-100; Majamaa 1991: 524-525). Ahlqvist otti ensimmäisenä viron kielen kokonaisuudessaan opetusohjelmaan kiinnittäen huomiota myös käytännön kielitaitoon. Hän tilasi Virosta jo dosenttina toimiessaan lukuvuonna 1860-61 oppikirjaksi F. R. Kreutzwaldin saksasta kääntämän teoksen Reinuwader Rebane (kirje Theodor Beiselle 29.3.1860, Ahlqvist 1982: 90) ja suomensi sen.

August Ahlqvist nimitettiin Elias Lönnrotin jälkeen vuonna 1863 suomen kielen ja kirjallisuuden professoriksi. Hän piti edeltäjänsä vaatimustasoa liian alhaisena ja korotti suomen kielen tutkintovaatimuksia. Lähisukukielten, erityisesti viron, osuus tuli entistä tärkeämmiksi. (Wichmann 1928: 295; Korhonen: 1993: 58.) Professori pyrki itse laatimaan opintoja varten apuneuvoja. Viron kirjallisuudestahan oli jo käytettävissä hänen 1855 tekemänsä - tosin ei enää aivan ajantasainen - yleisesitys. Siihen sisältyi koko joukko kirjallisuusnäytteitä 
suomennoksineen, joten se palveli myös kielenopiskelua. Vuonna 1869 Ahlqvist julkaisi lähisukukielten lukemistoksi tarkoitetun teoksen Suomalainen murteiskirja tahi lukemisia Viron, Karjalan, Vatjan, Vepsän ja Liivin kielillä. Kielennäytteisiin tutustumista helpottivat kirjan lopussa olevat sanastot. Lukemiston kaikista kielennäytteistä on viron osuus yli puolet, runsaat sata sivua, minkä lisäksi siinä on kolmisenkymmentä sivua laaja kahdelle palstalle ladottu virolais-suomalainen sanasto, ensimmäinen laatuaan (Ahlqvist 1869: 1-114, 205-236).

Ahlqvist alkoi viron kursseillaan käyttää Reinuwader Rebasen sijasta Kreutzwaldin kansansatukokoelmaa Eestirahwa Ennemuistesed jutud. Suomalaisen Kirjallisuuden Seura oli julkaissut teoksen vuonna 1866 paljolti sihteerinsä Ahlqvistin myötävaikutuksella (Annist 1966: 81-90; Põldmäe 1976: 490). Asiantuntijat olivat todenneet seuralle, että "Wiron sadut meillä saavat paljon lukioita. Niitten oma luonto viehättää; halu sukukielten tutkimiseen kasvaa apuneuvojen karttuessa." (Rothsten \& Godenhjelm 1868: 452.) Ensimmäiset sanakirjatkin saatiin opiskelun tueksi: Ahlqvistin oppilaan Torsten Gunnar Aminoffin tekemä Virolaissuomalainen sanakirja. Satukokoukseen: Eestirahva Ennemuistesed jutud ilmestyi samana vuonna 1869 kuin professorin Murteiskirja. Myöhemmin, vuonna 1882, julkaistiin Suomalais-virolainen sanasto Ahlqvistin lukemistoa varten, jonka oli laatinut O. A. F. Lönnbohm Murteiskirjan vironkielisen aineiston pohjalta.

\section{Ensimmäinen suomalainen viron kielioppi}

Suomalaisilta puuttui vielä omakielinen viron kielioppi. August Ahlqvisthan oli toistuvasti tähdentänyt kieliopin merkitystä kielten opiskelussa ja tutkimisessa. Itse hän ei kuitenkaan ryhtynyt kirjoittamaan viron kielioppia, vaan tämän työn otti harteilleen yliopiston suomen kielen ja kirjallisuuden dosentti Julius Krohn (1835-1888). Vuonna 1872 ilmestyi hänen tekemänsä Wiron Kielioppi Suomalaisille.

On kiinnostava sattuma, että ensimmäisen suomenkielisen viron kieliopin kirjoittaja oli osittain saksalaista syntyperää, kuten Virossa 
toimineet kielioppien tekijät. Viipurissa syntyneen Julius Krohnin isänpuoleinen suku oli kotoisin Saksasta Rügenin saarelta, äiti taas oli puoliksi Pietarin-saksalaisia, puoliksi inkerinsuomalainen. Julius vietti lapsuutensa Viipurin lähellä Kiiskilän kartanossa. Hänen äidinkielensä oli saksa, mutta jo lapsena hän oppi venäjää ja ranskaa sekä koulua varten ruotsia. Palvelusväen kanssa puhuttiin suomea ja ruotsia. Myöhemmin kouluvuosina tuntui voimakkaana kansallisuusliikkeen vaikutus, ja Julius Krohn alkoi opiskella tarmokkaasti suomea sekä tutustu koulukurssin vaatimuksia seikkaperäisemmin Kalevalaan ja sen kieleen. (Sarlin 1926.)

Krohn opiskeli Helsingin yliopistossa aluksi lääketiedettä ja täydensi kaiken aikaa suomen kielen taitoaan kirjoittamalla muun muassa Elias Lönnrotin johdolla aineita. Myöhemmin hän siirtyi yliopiston historiallis-kielitieteelliseen osastoon opiskelemaan historiaa, filosofiaa ja suomen kieltä. Suomen kielen tutkinnon Krohn suoritti Lönnrotille, ja hän oli ensimmäinen, joka yliopistossa kirjoitti suomenkielisen pro gradu -tutkielman. Filosofian kandidaatiksi hän valmistui 1860.

Julius Krohn meni naimisiin vuonna 1862. Hän ja hänen hyvä ystävänsä Yrjö Koskinen olivat ensimmäisiä sivistyneistöön kuuluneita, joiden perheissä puhuttiin ainoastaan suomea. Yksi Krohnin lapsista oli Kaarle, josta myöhemmin tuli kuuluisa kansanrunoustieteilijä. Vaimonsa kuoltua Krohn solmi uuden avioliiton, ja elokuussa 1878 syntyi tytär Aino Julia Maria, tuleva kirjailija Aino Kallas. Julius Krohnin akateeminen ura jatkui 1875 nimityksellä suomen kielen lehtoriksi, ja vuodesta 1885 kuolemaansa 1888 asti hän toimi suomen kielen ja kirjallisuuden ylimääräisenä professorina. (Remes 1995: 168-169.)

Julius Krohnin omakohtainen tutustuminen Viroon alkoi kesällä 1867, kun hän matkusti Yrjö Koskisen kanssa Tarttoon ja sieltä edelleen Võruun. Matkallaan miehet tapasivat Kreutzwaldin lisäksi muun muassa Kalevalan saksantajan Anton Schiefnerin, J. V. Jannsenin ja hänen tyttärensä Lydia Koidulan, jota Krohn kannusti opiskelemaan suomea.

Julius Krohn oli monipuolisesti kiinnostunut Virosta ja tutki kielen ohella esimerkiksi paikannimistöä, kansanrunoja sekä mytologiaa, 
josta suunnitteli kirjan tekemistä. Hän kirjoitti useita viron kieltä ja kirjallisuutta käsitteleviä artikkeleita. Krohn kiinnitti huomiota Kalevalan kielen ja viron suhteisiin ja oli sitä mieltä, että viron avulla saisivat selityksensä monet eepoksen oudot sanat. Niin ikään hän laati Kirjalliseen Kuukausilehteen F. J. Wiedemannin kieliopin Grammatik der Ehstnischen Sprache esittelyn pian teoksen julkaisemisen jälkeen 1875. (Sarlin 1926: 138-139; Remes 1995: 170.)

Julius Krohnin Wiron Kielioppi Suomalaisille -teoksen perustana olivat hänen omat luentonsa viron kieliopista sekä suomen ja viron eroista. Luonteeltaan kontrastiivisen oppikirjan pääasiallisina virolaisina lähteinä olivat Eduard Ahrensin kielioppi, F. J. Wiedemannin muutamaa vuotta aiemmin ilmestynyt virolais-saksalainen sanakirja sekä J. H. Rosenplänterin Beiträge-aikakauskirjat. Lisäksi hän sai asiantuntijaapua suoraan Wiedemannilta, Kreutzwaldilta ja Jakob Hurtilta. Krohn tiesi, että Wiedemann oli kirjoittamassa viron kielioppia, joka olisi niin ikään ollut hyvä lähdeteos, mutta hän ei voinut odottaa sen valmistumista oman kielioppinsa "kipeän tarpeen" vuoksi. Vertailussa suomeen oli Krohnin ensisijaisena tukena Gustav Erik Eurénin 1852 ilmestynyt Suomalainen Kielioppi Suomalaisille. (Krohn 1872: I-II, 55.)

August Ahlqvist, joka kirjoitti vuonna 1874 Krohnin kieliopista arvostelun Kielettäreen, piti virolaisten lähdeteosten valikoimaa suppeana ja materiaalinsa vuoksi sekavana sekä erityisesti Ahrensin kielioppia huonosti apuneuvoksi sopivana, sillä sen selkeydessä oli toivomisen varaa. Tämän seurauksena Krohnin teoksen selvyys kärsi. Lisäksi se oli dispositioltaan uuvuttavan moniportainen. Arvostelija piti myös pahana puutteena sitä, ettei Krohn ollut tutkinut kielioppiaan varten puhekieltä, vaan tukeutui vain kirjallisiin lähteisiin. (Ahlqvist 1874: 50-51.) Krohn tiedostikin tämän ongelman ja kirjoitti jo teoksensa (1872: I) esipuheessa: "Tämmöinen työ, voidaksensa tulla kaikin puolin kelvolliseksi, olisi vaatinut syvää viron puhekielen tuntemista; sillä meidän heimolaistemme kirjakieli on valitettavasti vielä niin kovin kirjava ja epäsäännöllinen ettei siihen ole paljon luottamista." Krohnin kieliopissa viron kirjakielen vakiintumattomuus ilmenee eri lähdeteoksista poimittujen 
esimerkkien esittämisessä: paikoin annetaan kolmekin rinnakkaismuotoa mainitsematta käyttötaajuuteen tai levinneisyyteen liittyviä tietoja.

Julius Krohnin Wiron Kielioppi on laajuudeltaan 225 sivua ja jakautuu kolmeen pääjaksoon: äänneoppiin, muoto-oppiin ja sananmuodostusoppiin ("sanainsynty-oppiin"), jossa käsitellään yhdyssanoja ja johdostyyppejä. Teoksessa ei ole erityistä lauseopin jaksoa, mutta muoto-opin yhteydessä kuvataan nominien ja verbien syntaktista käyttöä. Lopussa on lyhyt katsaus virolaisen kansanrunouden kieleen, kuten oli Ahrensin kieliopin ensimmäisessä osassakin.

Kielioppinsa johdannossa Krohn (1872: 1-5) oikoo Ahrensin käsitystä, että viro olisi eräiden kadonneiden mutta suomessa esiintyvien muotojen ja äänteellisen kuluneisuutensa perusteella suomen kielen tytär. Lukuisat äänne- ja muotopiirteet sekä suomen murteiden edustuksen vertaaminen lähisukukieliin osoittavat Krohnin mukaan, että viro ja suomi ovat sisarkieliä ja viro sisältää "hämäläisen sukuhaaran tärkeimpiä omituisuuksia”, ts. se on lähempänä länsimurteitamme kuin itäisiä itämerensuomalaisia kielimuotoja.

Krohn (1872: 8) luonnehti värikkäästi suomen ja viron rakenneeroja:

"Muutenkin on viron kielessä paljon säännötöntä, järjestyksetöntä, joka tekee sen kieliopin sangen sekavaksi ja vaikeaksi. Täytyy säätää paljon enemmän sääntöjä kuin suomessa ja niistä säännöistä poikkeavia sanoja vilskuu kuitenkin summattomasti. Suomen kielen rakennus on, kemiallista vertausta käyttääkseni, muodostunut hiljaisella, rauhallisella kiteytymisellä eli kristalliutumisella; viron kielessä sitä vastoin on kiteytyminen nähtävästi ollut yhäti häiritty. Siitä syystä ilahuttavat edellisen muodot tutkijan mieltä ihanalla säännöllisyydellään; jälkimäisessä törröttää vanhoja muotoja uudempain keskeltä, vieraita aineita näkyy jokapaikassa, kaikki on sekaisin, ylös-alaisin viskattu, temmattu ja revitty. Viron kieli-paralla on silminnähtävästi ollut sama kohtalo kuin meidän poloisilla Virolais-veljillämme; molemmat ovat yhä olleet sodan jaloissa ja sorron alla." 
Selvästikään tienraivaajan työ ei ollut aina helppoa eikä yksinkertaista, ja se kuvastuu myös hänen kirjoittamastaan kieliopista (kieliopin yksityiskohtaisemmasta tarkastelusta ks. Remes 1995: 171-174). August Ahlqvist (1874: 56) huomauttikin varsin kriittisen arvostelunsa loppupuolella tunnustavasti: "Jospa tämä ensimmäinen virolaisen kieliopin suomalainen koe ei, sen mukaan mitä nyt olemme lausuneet, siis ole virheetöin, niin on se kuitenkin tehnyt alun Suomalaisten tutkinnolle tällä alalla.”

\section{Lopuksi}

Eduard Ahrensin kieliopin ilmestyminen vuonna 1843 merkitsi huomattavaa kohennusta viron kielen kuvaamisessa sen rakennetta aiempaa paremmin vastaavalla tavalla. Porthanin Suomessa vuosisadan vaihteessa esittämä toive kelvollisesta viron kieliopista toteutui, ja samoin käynnistyi viron ortografian uudistamiseen johtanut kehitys, jollaista jo A. I. Arwidsson oli Beiträge-aikakauskirjassa 1822 esittänyt. Hän oli myös kiinnittänyt huomiota muun muassa siihen, että virossa on suomen tavoin kaasuksia enemmän kuin vain kuusi latinan kieliopin mallin mukaan esitettyä muotoa. (Arwidsson 1822: 124-130; Kask 1958: 53-54.) Onnekas sattuma oli, että Elias Lönnrotin Viron-matka saattoi toteutua vasta pian Ahrensin kieliopin ilmestymisen jälkeen. Näin siinä esitetyt ajatukset antoivat aihetta merkittävän suomalaisen kielimiehen sekä Virossa viron kieltä tutkineiden ja harrastaneiden välisiin keskusteluihin. Niin ikään Ahrensin teos oli tukena tärkeissä kielivertailuissa, joita Lönnrot esitti matkakirjeissään ja eräissä myöhemmissä artikkeleissaan. Paljolti Lönnrotin matkan asniosta Ahrens tuli Suomessakin tunnetuksi, ja hänet kutsuttiin vuonna 1845 Suomalaisen Kirjallisuuden Seuran kirjeenvaihtajajäseneksi.

Ilman Ahrensin uudentyyppistä viron kielioppia olisi Julius Krohnin työ suomalaisille tarkoitetun viron kieliopin laatimisessa ollut vaikeaa, ja Ahlqvist olisi saanut enemmänkin aihetta arvosteleviin kannanottoihinsa. Wiedemannin tieteellisempi ja järjestelmällisempi kielioppihan ei 
ollut vielä ehtinyt ilmestyä Krohnin työtä tukemaan. Vuonna 1872 julkaistu Wiron Kielioppi oli usean vuosikymmenen ajan tärkein heimokielen opiskelun apuneuvo, joka suomalaisilla oli käytettävissä, ennen kuin 1900-luvulla alkoi Lauri Kettusen oppikirjatuotanto. Krohnin kieliopin ja Wiedemannin sanakirjan avulla tutustui esimerkiksi nuori Eino Leino (1965 [1925]: 171) Lydia Koidulan ja Anna Haavan runoihin ja samalla laajemminkin viron kieleen. Ahrensin kielioppi vaikutti siten epäsuorasti, Julius Krohnin välityksellä, vielä ptkään ilmestymisensä jälkeen suomalaisten viron opiskeluun ja käsitykseen viron kielen luonteesta.

\section{Lähteet}

Ahlqvist, August 1856. Wiron nykyisemmästä kirjallisuudesta. - Suomi 1855. Femtonde årgången. Helsinfors, 1-109.

Ahlqvist, August 1869. Suomalainen murteiskirja tahi lukemisia Viron, Karjalan, Vatjan, Vepsän ja Liivin kielillä suomalaisten sanastojen kanssa. Helsinki: Simeliuksen Perillisten Kirjapainossa.

Ahlqvist, August 1874. J. Krohnin teoksen Wiron Kielioppi Suomalaisille: arvostelu. - Kieletär 6, 50-56.

Ahlqvist, August 1982. Kirjeet. Kielimiehen ja kaukomatkailijan viestejä 1845-1889. Maija Hirvonen, Kaisu Lahikainen (toim.). SKS:n toimituksia 374. Helsinki: Suomalaisen Kirjallisuuden Seura.

Ahrens, Eduard 1843. Grammatik der Ehstnischen Sprache Revalschen Dialektes. Reval: Heinrich Laakmann.

Ahrens, Eduard 1853. Grammatik der Ehstnischen Sprache Revalschen Dialektes. Reval: Kluge und Ströhm.

Annist, August 1966. Friedrich Reinhold Kreutzwaldi muinasjuttude algupära ja kunstiline laad. Tallinn: Eesti Raamat.

Anttila, Aarne 1985. Elias Lönnrot: elämä ja toiminta. Toinen painos. SKS:n toimituksia 417. Helsinki: Suomalaisen Kirjallisuuden Seura.

Ariste, Paul 1973. Ferdinand Johann Wiedemann. Tallinn: Valgus.

Arwidsson, A. I. 1822. Ueber die ehstnische Ortographie. - Beiträge zur genauern Kenntniss der ehstnischen Sprache XV, 124-130.

Haltsonen, Sulo 1961. August Ahlqvistin Vatjan ja Viron matkat v. 1854-1855. Virittäjä 65 (1), 222-231.

Häkkinen, Kaisa 1994. Agricolasta nykykieleen. Suomen kirjakielen historia. Helsinki: WSOY. 
Kasik, Reet 1999. Johdatus viron kielen tutkimukseen. Castrenianumin toimitteita 55. Helsinki: Suomalais-ugrilainen laitos, Suomalais-Ugrilainen Seura.

Kask, Arnold 1958. Võitlus vana ja uue kirjaviisi vahel XIX sajandi eesti kirjakeeles. Eesti NSV Teaduste Akadeemia Emakeele Seltsi Toimetised 2. Tallinn: Eesti Riiklik Kirjastus.

Kask, Arnold 1970. Eesti kirjakeele ajaloost I. Tartu: Tartu Riiklik Ülikool, Eesti keele kateeder.

Korhonen, Mikko 1993. August Ahlqvist kielitieteilijänä. - Jaakko Anhava (toim.). Suomen kieli, Suomen mieli. August Ahlqvist vaikuttajana. Suomi 171. Helsinki: Suomalaisen Kirjallisuuden Seura, 55-69.

Krohn, Julius 1872. Wiron Kielioppi Suomalaisille. Helsinki: Suomalaisen Kirjallisuuden Seura.

Kuningas, Oskar 1977. E. Lönnroti viibimisest Rõuges. - Keel ja Kirjandus 4, 239-240.

Leino, Eino 1965 [1925]. Elämäni kuvakirja. Ensimmäinen nide. - Eino Leino, Muistelmat 1. Helsinki: Otava, 5-216.

Lönnrot, Elias 1902. Elias Lönnrotin matkat. II osa: Vuosina 1841-1844. SKS:n toimituksia 98. Helsinki: Suomalaisen Kirjallisuuden Seura.

Lönnrot, Elias 1990. Valitut teokset 1. Kirjeet. Raija Majamaa (toim.). SKS:n toimituksia 510. Helsinki: Suomalaisen Kirjallisuuden Seura.

Lönnrot, Elias 1991. Valitut teokset 3. Kirjoitelmia ja lausumia. Raija Majamaa (toim.). SKS:n toimituksia 551. Helsinki: Suomalaisen Kirjallisuuden Seura.

Majamaa, Raija 1990. Taustatietoja. - Elias Lönnrot, Valitut teokset 1. Kirjeet. Raija Majamaa (toim.). SKS:n toimituksia 510. Helsinki: Suomalaisen Kirjallisuuden Seura.

Majamaa, Raija 1991. Taustatietoja. - Elias Lönnrot, Valitut teokset 3. Raija Majamaa (toim.). SKS:n toimituksia 551. Helsinki: Suomalaisen Kirjallisuuden Seura.

Niit, Heldur 1986. Lisaandmeid Elias Lönnroti Eestis käigu kohta. - Keel ja Kirjandus 6, 321-329; 7, 403-411.

Porthan, Henrik Gabriel 1982. Valitut teokset. Kääntänyt, esipuheen ja johdannot kirjoittanut Iiro Kajanto. SKS:n toimituksia 373. Helsinki: Suomalaisen Kirjallisuuden Seura.

Põldmäe, Rudolf 1976. August Ahlqvist ja tema suhted Eestiga. - Keel ja Kirjandus 8, 489-491.

Pääkkönen, Irmeli 1994. Viron kielen opetusta Helsingin yliopistossa 1830-luvulla. Lähivertailuja 8. Helena Sulkala, Heli Laanekask (toim.). Oulun yliopiston 
suomen ja saamen kielen laitoksen tutkimusraportteja 40. Oulu: Oulun yliopisto, 98-105.

Remes, Hannu 1995. Ensimmäinen suomalainen viron kielioppi. - Jaak Peebo (toim.). Läänemere rahvaste kirjakeelte ajaloost. Tartu Ülikooli eesti keele õppetooli toimetised 1. Tartu: Tartu Ülikooli Kirjastus, 164-175.

Remes, Hannu 2003. Elias Lönnrotin ajatuksia viron kielestä. - Lähivertailuja 13. Pirkko Muikku-Werner, Hannu Remes (toim.). VIRSU. Viro ja suomi: kohdekielet kontrastissa. Joensuu: Joensuun yliopisto, 185-191.

Rothsten, F. W., B. F. Godenhjelm 1868. Lausunto Viron satujen sanakirjasta Suomalaisen Kirjallisuuden Seuran kokouksessa 8.1.1868. - Suomi II: 8. Helsinki: Suomalaisen Kirjallisuuden Seura, 447-453.

Rätsep, Huno 1979. Eesti keele ajalooline morfoloogia II. Tartu: Tartu Riiklik Ülikool, Eesti keele kateeder.

Sarlin, A. J. 1926. Julius Leopold Fredrik Krohn. Hänen elämänsä ja toimintansa. Helsinki: Otava.

Viht, Annika, Külli Habicht 2020. Eesti keele sõnamuutmine. Eesti keele varamu IV. Tartu: Tartu Ülikooli Kirjastus.

Wichmann, Yrjö 1928. Silmäys suomen ja sen sukukielten edustukseen vuosisadan kuluessa. - Gunnar Suolahti, Carl von Bonsdorff, Gunnar Castrén, Viljo Tarkiainen (toim.). Helsingin yliopiston alkuajoilta. Julkaissut Helsingin yliopisto Helsinkiin siirtymisen satavuotismuistoksi. Porvoo: WSOY, 98-105. 


\title{
Grammar of Eduard Ahrens and the Finns
}

\author{
HANNU REMES
}

Already at the turn of the 19th century, H. G. Porthan, professor at the Academy of Turku, took an active interest in Finnish and related languages and promoted their study in various ways. In his view, grammars were essential for a deeper knowledge of languages, and he missed a proper grammar of Estonian. The grammars of those times followed the model of Latin grammar-writing and failed to give an adequate description of, for instance, the inflection of nouns and verbs.

In 1843, finally, Eduard Ahrens, pastor at Kuusalu, published his Germanlanguage Grammatik der Ehstnischen Sprache Revalschen Dialektes, the first Estonian grammar to detach itself from Latin and German models and to rely on Finnish grammars, which were better suited to describe Estonian. In Ahrens's view, Estonian was a daughter of Finnish, a language which had evolved from Finnish by way of erosion. He also actively propagated a reform of the Estonian orthography following the model of Finnish.

Elias Lönnrot, the compiler of the national epic Kalevala, spent six months in Estonia in 1844. He met Ahrens and discussed various issues of grammar and orthography with him. Most of the time Lönnrot stayed in Tartu, where F. R. Faehlmann became his Estonian teacher and close friend. Lönnrot attempted to convince the members of the Estonian Learned Society (ÕES) of the necessity of an orthography reform. He was planning to use Ahrens's grammar and his newly-acquired fluent command of Estonian in writing a new comparative grammar of Finnish, Estonian, Veps and Saami; regrettably, this plan was never realized. Lönnrot made numerous observations on the relationship between Finnish and Estonian and reported them in his letters to Finland.

In the autumn of 1854, August Ahlqvist stayed in Estonia for a few months. He had repeatedly emphasized the importance of grammars, but his opinion on Ahrens's grammar was rather negative: in his view, it was chaotic and unsuitable for didactic use. The only positive aspect he saw was Ahrens's aspiration to reform the Estonian orthography. Soon after his visit to Estonia, Ahlqvist 
published Wiron nykyisemmästä kirjallisuudesta ('On contemporary Estonian literature'), which was one of the first scholarly works to appear in Finnish and the first important survey of Estonian literary culture. As the professor of Finnish at the University of Helsinki, Ahlqvist essentially promoted the teaching and study of the Estonian language in Finland. He sharpened the learning requirements for students of Finnish and increased the role of the Estonian language. Thanks to him, some sorely needed coursebooks were produced.

In 1872, Wiron Kielioppi ('Estonian grammar') by Julius Krohn appeared, the first Finnish-language grammar of Estonian. In writing his grammar, Krohn had mostly relied on Ahrens (for this, he was heavily criticized by Ahlqvist) and on the Estonian-German dictionary of Wiedemann. Despite his criticism, Ahlqvist praised Krohn for extending the scope of linguistic studies in Finland. By way of Krohn's grammar, the influence of Ahrens's grammar prevailed in Finland throughout decades; more descriptions of the Estonian language for and by Finns only appeared in the early 20th century.

Keywords: Estonian grammar; Estonian language education; Eduard Ahrens; Elias Lönnrot; August Ahlqvist; Julius Krohn

\section{Hannu Remes}

hannu.o.remes@gmail.com 